\title{
ANALIZA SWOT A DOMENIULUI RESPONSABILITĂȚII SOCIALE CORPORATIVE ÎN ROMÂNIA
}

\author{
Ana-Petrina PĂUN ${ }^{\circledR}$, drd., asist.univ.,
}

Universitatea Petroșani, România

DOI: https://doi.org/10.36004/nier.cdr.2019.14-13

JEL Classification: M14.

Lucrarea debutează cu o scurtă trecere în revistă a evoluției responsabilității sociale corporative în România. În cuprinsul lucrării am prezentat cadrul instituțional și actorii cheie cu atribuții în sfera operaționalizării conceptului de RSC în țara noastră. Pe baza consultării articolelor științifice și a lucrărilor apărute recent în literatura de specialitate din România, am realizat o sinteză a aspectelor referitoare la analiza SWOT a dezvoltării și implementării conceptului RSC - scopul principal fiind acela de a spori gradul de conştientizare cu privire la importanţa şi beneficiile adoptării responsabilităţii sociale şi de a creşte implicarea factorilor decizionali în aplicarea acesteia în România.

Cuvinte-cheie: responsabilitate socială corporativă, factori cheie, analiză SWOT.

The work begins with a brief overview of the evolution of corporate social responsibility in Romania. In the paper I presented the institutional framework and key factors which have responsibilities in the field of operationalizing the concept of CSR in our country. Based on the consultation of the scientific articles and of the papers recently published in the Romanian literature, we made a synthesis of the aspects related to the SWOT analysis of the development and implementation of the CSR concept - the main purpose being to increase the awareness of the importance and the benefits adopting social responsibility and increasing the involvement of decision-makers in its application in Romania.

Key words: corporate social responsibility, key factors, SWOT analysis.

În România, conceptul de responsabilitate socială corporativă a apărut în anii 1990, o dată cu apariţia ONG-uri, în special a unora cu scop umanitar, fondate cu sprijinul instituţiilor internaţionale, publice sau private. Acest fenomen a fost urmat în anii 2000 de anumite reforme, ca parte a pregătirii ţării noastre pentru integrarea în Uniunea Europeană. Aceste reforme au influenţat implicarea companiilor mari şi mici în activităţi de responsabilitate socială corporativă, ce au constat în înlocuirea tehnologiilor de producţie, datorită presiunilor legate de mediu înconjurător şi de legislaţie, care trebuiau să asigure protejarea mediului şi a omului, precum şi pentru promovarea dezvoltării durabile a societăţii.

O dată cu integrarea ţării noastre în Uniunea Europeană, companiile româneşti au început să conştientizeze efectele pozitive ale aplicării responsabilităţii sociale şi să se implice în acest domeniu, care cuprinde diverse activităţi ce presupun responsabilităţi comune din partea autorităţilor publice, sectorului privat şi societăţii.

Apariţia Directivei 2014/95/UE prin care se stipulează obligativitatea raportării rezultatelor non-financiare de către marile corporații din statele europene pare să fi prins "pe picior greșit" factorii decizionali din România și companiile din mediul autohton care se află sub incidența acestui act normativ. Indiferent de opțiunea aleasă de fiecare companie, informațiile non-financiare fac referire la: aspectele legate de protecția mediului, problemele sociale și cele legate de gestiunea resurselor umane (inclusiv elemente ce țin de sănătatea și securitatea ocupațională), situația respectării drepturilor omului și combaterea fenomenelor de corupție și de mită, în măsura în care, abordarea acestor subiecte este de natură să confere un plus de înțelegere în ceea ce privește

\footnotetext{
๑ Ana-Petrina Păun, paun.anapetrina@gmail.com
} 
strategiile de creștere, performanțele și impactul pe care o companie le generează la nivelul comunităţii în care acționează, în planul dezvoltării durabile [7].

La nivelul anului 2017, numărul corporațiilor românești care reușiseră să se adapteze "din mers" acestei rigori legislative noi era cuprins între 20-30 entități economice, dintr-un total de 680 de organizații de afaceri cu peste 500 de angajați care aveau obligativitatea de a emite un raport non financiar, cu evidențierea distinctă a performanțelor înregistrate în materie de securitate și sănătate în muncă. Având în vedere aceste evoluții recente, consider că analiza resorturilor interne și a particularităților care au determinat performerii responsabilității sociale să se alinieze acestei tendințe europene noi în materie de raportare, este de natură să stimuleze benchmarkingul la nivelul corporațiilor românești și să-i determine pe managerii care nu au identificat încă resursele necesare pentru a se circumscrie acestui trend să adopte măsuri rapide pentru recuperarea decalajelor.

Promovarea transparenței în ceea ce privește mediul de business și amplificarea cantitativă și calitativă a informațiilor non-financiare puse la dispoziția stakeholderilor de către corporațiile care activează în diferite sectoare de activitate, reprezintă aspecte fundamentale a căror dezvoltare se află în continuare printre priorităţile de pe agenda Uniunii Europene. Este unanim recunoscut faptul că statele dezvoltate din Vestul Europei reprezintă modele de înalt angajament și conștientizare în ceea ce privește raportarea de RSC/sustenabilitate [9].

Implementarea şi dezvoltarea RSC cuprinde o gamă diversă de activităţi ce presupun responsabilităţi comune din partea mai multor actori-cheie [1]: autorităţi publice, reprezentanţi ai angajatorilor şi angajaţilor, organisme şi organizaţii de RSC şi instituţiile de educaţie şi cercetare.

Rolul major al autorităților publice este acela de a asigura un mediu legislativ favorabil pentru operaţionalizarea conceptului RSC. Ulterior integrării României în Uniunea Europeană au fost realizate îmbunătățiri semnificative ale actelor normative cu privire la protecția mediului înconjurător, sănătatea și securitatea angajaților, incluziunea socială a persoanelor cu dizabilități, voluntariat și protecția civilă, transparență și anticorupție etc. În 2011, odată cu elaborarea Strategiei Naţionale de Promovare a RSC, autorităţile publice din România au recunoscut importanţa creşterii conştientizării şi sprijinirii dezvoltării domeniului RSC în România, identificând punctele slabe şi stabilind obiective specifice, armonizate cu strategia UE. Pot fi remarcate o serie de iniţiative generate de către instituţiile şi autorităţile publice specifice domeniului de RSC ce cuprind prevenirea sau reducerea poluării, promovarea oportunităţilor egale pentru femei şi bărbaţi şi a lipsei de discriminare la locul de muncă, promovarea siguranţei rutiere, a incluziunii sociale a persoanelor cu dizabilităţi, reducerea mitei şi a corupţiei în instituţiile şi autorităţile publice. Iniţiativele de interes pentru domeniul de RSC au fost însă destul de puţine la număr, instituţiile şi autorităţile publice fiind adesea un partener secundar în proiecte şi campanii, nu principalul iniţiator.

Reprezentanţilor angajatorilor şi angajaţilor le revine un rol cardinal în stimularea implementării practicilor de business responsabile. Prin însăşi natura lor, aceste tipuri de organizaţii se află în linia întâi din punct de vedere al dialogului cu companii, întreprinderi, uniuni şi alţi actori, atât prin intermediul unor organizaţii comune (de exemplu Camera de Comerţ din România), precum şi prin intermediul unor organizaţii specifice anumitor industrii (de exemplu Federaţia Uniunilor de Ciment din România) - în studiul Responsabilitate Socială Corporativă în România. Analiză situaţională și recenzie a practicilor actuale, realizat în cadrul Proiectului POSDRU "Întărirea capacității companiilor românești de dezvoltare a parteneriatelor sociale - RSC", au fost inventariate o serie de iniţiative desfăşurate de reprezentanţi ai angajatorilor şi angajaţilor în domeniul RSC. Deși cea mai mare parte tind să se axeze pe o componentă specifică - precum sănătatea şi siguranţa angajaţilor, dezvoltarea abilităţilor şi aptitudinilor angajaţilor sau eficienţa în domeniul mediului înconjurător - au fost identificate câteva iniţiative care se concentrează pe promovarea şi încurajarea integrării unei abordări responsabile în ansamblu în operaţiunile de business. Actorii cheie şi strategiile acestora în domeniul RSC sunt sistematizaţi în Fig. 1. 
Camera de Comerţ din România este unul dintre actorii majori care derulează astfel de proiecte, promovând conceptul de RSC în ansamblul său şi desfăşurând iniţiative conexe, la nivel naţional şi local, prin intermediul birourilor regionale. Spre deosebire de Camerele de Comerţ, al căror interes şi implicare în domeniul de RSC şi domenii conexe a crescut semnificativ în ultimii ani, asociaţiile profesionale sunt mai puţin conştiente de rolul şi impactul potenţial pe care 1-ar putea avea în societate dacă ar promova practici de business responsabile şi și-ar aduce aportul la dezvoltarea unui mediu de business care să acţioneze responsabil.

De menționat și rolul instituțiilor de educație și de cercetare care, în plan teoretic, este acela de a contribui la mai buna cunoaștere a domeniului RSC la nivel național și internațional, iar în plan pragmatic acela de a asigura formarea și dezvoltarea competențelor pentru RSC. Dacă în ceea ce privește organizarea de conferințe, seminarii și workshopuri în domeniu, instituțiile de educație s-au constituit în nuclee de dezbateri și de diseminare a celor mai importante rezultate și practici din domeniu, acestea nu au folosit în mod corespunzător oportunitatea de a contribui la profesionalizarea RSC prin construcția unei curricule universitare adaptate ultimelor evoluții din mediul de business și care să cuprindă programe de studii dedicate. Astfel, se constată că subiectul RSC nu face obiectul unor programe de studii de licență sau masterat de sine-stătătoare în universitățile din România. Anumite paliere ale domeniului (etica în afaceri, protecția mediului, relațiile comunitare) pot forma pachete de discipline din curricula unor programe academice precum Management, Asistență Socială, Marketing, Comunicare, dar acestea abordează doar tangențial impactul afacerilor asupra mediului sau contribuţia companiei în societate prin promovarea unui comportament de business responsabil.

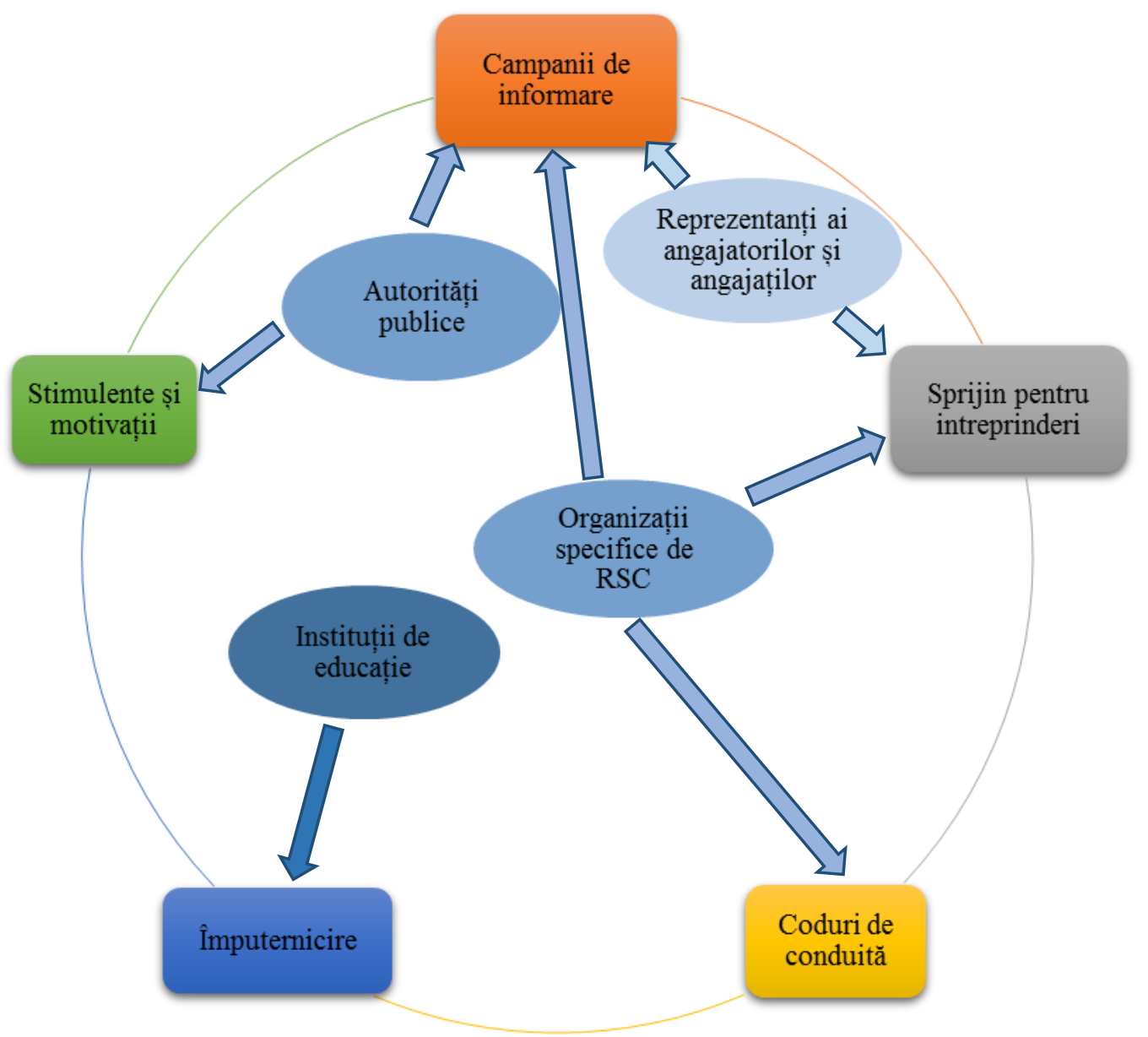

Figura. 1. Actorii cheie și strategiile acestora în domeniul RSC

Sursa: Anca C., Aston J., Stanciu E., Rusu D. Responsabilitate Socială (Corporativă) în România. Analiză situațională și recenzie a practicilor actuale. Raport realizat în cadrul Proiectului POSDRU/64/3.3/S/41722 "Întărirea capacității companiilor românești de dezvoltare a parteneriatelor sociale - RSC”, 2011.[1] 
În domeniul cercetării, situația este oarecum asemănătoare în sensul că deși există o serie de studii cu privire la diferite teme desprinse din problematica generală a RSC, puține au fost intreprinse la nivel național, iar cele derulate în cadrul companiilor private au fost inițiate de departamentele de Management, Comunicare sau Marketing și nu de către structuri specializate de RSC. Există și în sfera cercetării un punct forte care trebuie evidențiat și anume, inițiativa cadrelor didactice de la Academia de Studii Economice din București (Facultatea de Marketing) de a lansa prima rețea academică de cercetare din domeniul RSC, ROnet SRR (The Romanian Network for Social Responsibility Research), cu scopul de a mijloci colaborarea interuniversitară pentru dezvoltarea de programe educaționale dedicate și proiecte de cercetare comune, dar și pentru organizarea de traininguri, workshopuri și/sau conferințe ori furnizarea de informații și acordarea de consultanță pentru dezvoltarea domeniului la nivel național și internațional [1].

Pe de altă parte, în România au fost dezvoltate platforme de comunicare moderne - reţele, forumuri, bloguri şi website-uri dedicate problematicii RSC şi dezvoltării durabile. Importanța acestora în ceea ce privește conștientizarea conceptului RSC, furnizarea de instrumente, promovarea şi menţinerea dialogului în domeniu, precum şi comunicarea de bune practici bune este esențială dacă luăm în calcul faptul că aceste platforme sunt situate la interfaţa dintre societatea civilă şi organizaţiile publice şi private. La momentul actual, mediul online reprezintă o sură extrem de importantă de informatiii în domeniul RSC. Cele mai relevante platforme de comunicare în domeniul RSC sunt: www.responsabilitatesociala.ro, www.csrreport.ro, www.csr-romania.ro, www.csrmedia.ro, www.stiri.ong, www.csrawards.ro etc.

Pe baza celor menționate, dar și a consultării unui număr important de articole știinţifice și lucrări apărute recent în literatura de specialitate din România, voi realiza în rândurile următoare o sinteză a aspectelor referitoare la analiza SWOT a dezvoltării și implementării conceptului RSC în România. Analiza SWOT este întâlnită, de regulă, sub forma unei matrici cu 2 linii și 2 coloane conform Tabelului 1.

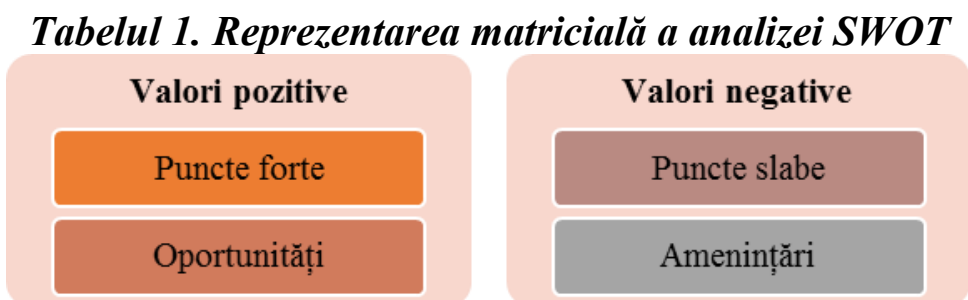

Sursa: Ivorschi R. Analiza SWOT - instrument managerial pentru eficientizarea activității, Romanian Statistical Review, 2012, nr. 5 [6]

Scopul principal al utilizării analizei SWOT în sfera RSC este de a spori gradul de conştientizare cu privire la importanţa şi beneficiile adoptării responsabilităţii sociale şi de a creşte implicarea sectorului public, a companiilor româneşti, precum şi a societăţii civile în aplicarea acesteia în ţara noastră. În România, responsabilitatea socială corporativă nu se mai află la început de drum; atât companiile, cât şi publicul larg încep să devină din ce în ce mai conştienţi de ceea ce reprezintă acest domeniu. Companiile devin din ce în ce mai preocupate de necesitatea, dar şi de beneficiile unei abordări responsabile faţă de societate, dar mai mult, performanţa acestora, indiferent de forma lor (privată sau publică), se află în strânsă legătură cu gradul de dezvoltare a comunităţii în care activează.

Având în vedere faptul că performanţele şi abordările în sfera responsabilităţii sociale a companiilor pot influenţa aspecte cheie privind reputaţia, avantajul competitiv al companiei şi relaţia cu stakeholderii, integrarea conceptului de responsabilitate socială în procesul de luare a deciziilor de către companii are efecte pozitive imediate asupra beneficiarilor direcţi, asupra comunităţilor şi a societăţii în general. Astfel, crearea unui cadru legal la nivel naţional reprezintă 
un factor determinant de promovare a dezvoltării economice, a dezvoltării sustenabile a comunităţilor şi societăţii. Rezultatele analizei SWOT sunt centralizate în Tabelul 2.

Tabelul 2. Analiza SWOT a domeniului RSC în România

\begin{tabular}{|c|c|}
\hline Puncte tari & Puncte slabe \\
\hline $\begin{array}{l}\text { - Deschidere şi interes ale societăţii în general către RSC şi } \\
\text { relativa noutate a conceptului în spaţiul public; } \\
\text { - Existența unui transfer de know-how din partea } \\
\text { multinaționalelor cu o cultură corporativă consolidată } \\
\text { către mediul de afaceri românesc în sfera implementării } \\
\text { inițiativelor de RSC; } \\
\text { - Creşterea continuă a numărului de iniţiative de tip RSC şi } \\
\text { de bune practici în acest domeniu la nivel naţional; } \\
\text { - Existența unor platforme de comunicare moderne - reţele, } \\
\text { forumuri, bloguri şi website-uri în domeniul } \\
\text { responsabilităţii sociale ca sursă de informații în domeniu } \\
\text { și instrument de diseminare a conceptelor și bunelor } \\
\text { practici de RSC în societate; } \\
\text { - Tendința CMN de a opera mutația de la filantropie şi } \\
\text { voluntariat spre forme mai evoluate de intervenţie în } \\
\text { domeniul RSC, de tipul practicilor corporative } \\
\text { responsabile social; } \\
\text { - Orientarea programelor RSC spre domenii de intervenție } \\
\text { ’sensibile" din perspectiva societății româneşti: rezolvarea } \\
\text { problemelor comunității, protecția mediului ambiant, } \\
\text { educația etc. } \\
\text { - Creşterea interesului consumatorilor pentru } \\
\text { produsele/serviciile companiilor responsabile social. }\end{array}$ & $\begin{array}{l}\text { - Cunoaştere insuficientă a conceptului de RSC la } \\
\text { nivelul societăţii; } \\
\text { - Absenţa unor studii, cercetări şi evaluări sociologice } \\
\text { ample asupra gradului de cunoaştere şi aplicare a RSC } \\
\text { în România; } \\
\text { - Slabă cunoaştere şi implicare a organizaţiilor şi } \\
\text { întreprinderilor mici şi mijlocii în iniţiative de RSC; } \\
\text { - Slabă coordonare a actorilor cheie din sfera RSC în } \\
\text { ceea ce privește programele de responsabilitate socială, } \\
\text { pe fondul implicări insuficiente a unora dintre aceștia } \\
\text { (autorități guvernamentale, reprezentanţi ai } \\
\text { angajatorilor, instituții de cercetare/educație); } \\
\text { - Resurse financiare insuficiente pentru programe de } \\
\text { RSC, care au suportat reduceri suplimentare pe } \\
\text { perioada crizei; } \\
\text { - Unele dintre organizațiile de afaceri românești, percep } \\
\text { încă RSC ca un instrument de PR (public relations) și } \\
\text { îl implementează prin simpla "imitare" a unor practici } \\
\text { specifice multinaționalelor; } \\
\text { - Absența unor specializări universitare în domeniul } \\
\text { RSC, precum şi a unor cursuri de formare şi dezvoltare } \\
\text { a competențelor specifice; } \\
\text { - Lipsa coerenței în ceea ce privește integrarea strategiei } \\
\text { RSC în strategia globală de afaceri a companiei. }\end{array}$ \\
\hline Oportunități & Amenințări \\
\hline $\begin{array}{l}\text { - Beneficii pentru companii, societate, mediu de afaceri, } \\
\text { mediu înconjurător etc. ale unei abordări strategice care să } \\
\text { integreze RSC; } \\
\text { - Importanţa RSC la nivel european şi internaţional; } \\
\text { - Oportunităţi de dezvoltare şi implicare în piaţa europeană } \\
\text { pentru IMM-uri; } \\
\text { - Generarea de avantaje competitive pentru întreprinderile } \\
\text { româneşti pe piaţa europeană şi internaţională; } \\
\text { - Oportunitatea de a învăţa, prelua şi adapta bune practici } \\
\text { din experienţa altor state mai dezvoltate; } \\
\text { - Creşterea reputaţiei companiilor prin eforturile RSC; } \\
\text { - Oportunităţi de finanţare pentru iniţiative de RSC oferite } \\
\text { de UE; } \\
\text { - Atitudine pozitivă a cetăţenilor cu privire la implicarea } \\
\text { companiilor în comunitate; } \\
\text { - Un mediu înconjurător mai protejat de efectele } \\
\text { negative ale activităţilor umane. }\end{array}$ & $\begin{array}{l}\text { - Absenţa unor politici publice coerente de promovare a } \\
\text { RSC; } \\
\text { - Absenţa unui cadru legislativ coerent şi consistent; } \\
\text { - Deficiențe în aplicarea legislaţiei; } \\
\text { - Întârzieri privind standardele acceptabile în domeniile } \\
\text { conexe RSC (ex. mediu înconjurător) în comparaţie cu } \\
\text { alte state membre UE; } \\
\text { - Riscul de excludere sau blocare a accesului } \\
\text { companiilor româneşti pe anumite piețe; } \\
\text { - Suport şi implicare insuficientă a autorităţilor publice } \\
\text { în promovarea şi aplicarea RSC; } \\
\text { - Lipsa fondurilor bugetare pentru promovarea aplicării } \\
\text { RSC. }\end{array}$ \\
\hline
\end{tabular}

Sursa: Adaptare și actualizare după:

- $\quad$ Anca C., Aston J., Stanciu E., Rusu D. Responsabilitate Socială (Corporativă) în România. Analiză situațională și recenzie a practicilor actuale. Raport realizat în cadrul Proiectului POSDRU/64/3.3/S/41722 - Întărirea capacității companiilor românești de dezvoltare a parteneriatelor sociale - RSC [1].

- Strategia Naţională de Promovare a Responsabilităţii Sociale, 2011-2016. http://www.sgg.ro/nlegislativ/docs/2011/05/2x4bdfjnwskv89h17pzq.pdf (accesat la data de 20.05.2019) [8]. 
Concluzii: Actualmente, putem afirma că România parcurge o etapă de maturizare calitativă şi cantitativă în ceea ce privește implementarea conceptului de RSC.

Foarte importante sunt rezultatele analizei SWOT privind dezvoltarea RSC în România, dintre care atrag atenţia punctele slabe cu referire la: aspectele legate de cunoaşterea insuficientă a conceptului de RSC la nivelul societăţii corelată cu absenţa unor studii, cercetări şi evaluări asupra gradului de cunoaştere şi aplicare a RSC; slaba cunoaştere şi implicare a organizaţiilor şi intreprinderilor mici şi mijlocii în iniţiative de RSC şi slaba aplicare a investiţiilor şi achiziţiilor social responsabile sau implicarea superficială a organizaţiilor în activități de RSC, fără abordarea cauzelor problemelor sociale.

În acelaşi timp, pericolele semnalate vizează absenţa unor politici publice de promovare a RSC, absenţa unui cadru legislativ coerent şi consistent şi deficiențe în aplicarea legislaţiei; intârzieri privind standardele acceptabile în domeniile conexe RSC (ex. mediu inconjurător) în comparaţie cu alte state membre U.E. şi riscul de excludere sau blocare a accesului companiilor româneşti pe anumite pieţe. La acestea se adaugă şi sprijinul şi implicarea insuficientă a autorităţilor publice în promovarea şi aplicarea RSC alături de lipsa fondurilor bugetare pentru promovarea aplicării RSC.

În ceea ce privește punctele tari este de remarcat faptul că: există interes al societăţii în general către RSC; creşte continuu numărul de iniţiative de tip RSC; există platforme de comunicare moderne - reţele, forumuri, bloguri şi website-uri în domeniul responsabilității sociale şi creşte interesului consumatorilor pentru produsele/serviciile companiilor responsabile social.

Printre oportunități pot fi menționate: dezvoltarea IMM-urilor şi implicarea acestora în piaţa europeană; oportunitatea de a învăţa, prelua şi adapta bune practici din experienţa altor state mai dezvoltate; oportunitatea de finanţare pentru iniţiative de RSC oferite de UE; un mediu inconjurător mai protejat de efectele negative ale activităţilor umane.

\section{Bibliografie}

1. Anca C., Aston J., Stanciu E., Rusu D. Responsabilitate Socială (Corporativă) în România. Analiză situațională și recenzie a practicilor actuale. Raport realizat în cadrul Proiectului POSDRU/64/3.3/S/41722 "Întărirea capacității companiilor românești de dezvoltare a parteneriatelor sociale - RSC", 2011.

2. Dura C., Isac C., Ghicajanu M. Responsabilitatea socială corporativă. Fundamente teoretice și studii de caz, Petroșaniș Editura Universitas, 2018.

3. Filip R., Iamandi I. Etică și responsabilitate social corporativă în afacerile internaţionale. București: Editura Economică, 2008.

4. Gangone A.D. Responsabilitate social corporatistă. Repere conceptuale. Abordări strategice. Particularități culturale, București: Editura Universitară, 2016.

5. Iamandi I.E. Responsabilitatea socială corporativă în companiile multinaţionale. București: Editura Economică, 2010.

6. Ivorschi R. Analiza SWOT - instrument managerial pentru eficientizarea activității. Romanian Statistical Review, 2012, nr. 5.

7. Obligativitatea raportării non-financiare de către companii din UE - Impactul Directivei 2014/95/UE asupra mediului de afaceri din România. Policy Memo 57, CRPE, 2014.

8. Strategia Naţională de Promovare a Responsabilităţii Sociale, 2011-2016. www.sgg.ro/nlegislativ/docs/2011/05/2x4bdfjnwskv89h17pzq.pdf (accesat la data de 20.05.2019).

9. Survey of Corporate Responsibility Reporting, KPMG, 2017.

10. The CSR Report. www.csrreport.ro.

11. CSR Romania. www.csr-romania.ro.

12. Responsabilitate Sociala. Companii responsabile in Romania, studii de caz si know-how despre CSR. www.responsabilitatesociala.ro. 